\title{
The One Class of Vessel that is Impossible to Build in Australia Canada ${ }^{1}$
}

\section{Jason Delaney}

Le service sous-marin canadien n'a vraiment eu que deux programmes d'acquisition réussis, les deux d'origine britannique: le programme de la classe Oberon dans les années 1960 et l'acquisition de la classe Victoria dans les années 1990. Cependant, au niveau de la planification des forces, il y a eu de nombreuses propositions de projets des États-Unis ainsi que des pays du Commonwealth. D'étroites relations de travail avec d'autres marines ont permis aux planificateurs de guerre canadiens de suivre les dernières idées et le progrès dans la conception et la technologie sous-marines, mais le soutien n'a jamais existé au sein du gouvernement canadien, ni à la direction du ministère pour construire et maintenir une capacité d'attaque sous-marine nationale. L'acquisition des sous-marins est le seul achat de navire de guerre " tout fait 》 que le gouvernement est disposé à approuver, ce qui pose un problème pour le service et pour les achats futurs. Ce document se penche sur les tentatives d'établissement d'un programme national et, en même temps, l'envergure des mesures nécessaires pour suivre les développements dans d'autres pays du Commonwealth et chez d'autres alliés.

The first chapter of Peter Yule and Derek Woolner's book on the Collins-class submarine programme is entitled, "The One Class of Vessel that is Impossible to Build in Australia." Since the Australians went on to build their own attack submarines, perhaps this title would better suit a book on Canadian submarine procurement. The fact is that although Canada has never built its own submarines, Canadian industry has had the knowledge and experience to do so and the navy has always had the confidence to accomplish even the most technologically complex programme. The problem is that submarines are a hard sell to politicians and the general public especially after the end of the Cold War.

1 Borrowed from the title of the first chapter in Peter Yule and Derek Woolner's book on the Collins class project to make the point that there are many similarities between the Canadian and Australian experience except for the fact that the Australians were able to do what Canada has never been able to: build an indigenous submarine capability. Peter Yule and Derek Woolner, The Collins Class Submarine Story: Steel, Spies and Spin (Cambridge: Cambridge University Press, 2008), 3.

2 Yule and Woolner, Chapter 1.

The Northern Mariner/Le marin du nord XXIV, Nos. 3 \& 4 (Jul. \& Oct. 2014), 260-272 Canadian Military History 23, Nos. 3 \& 4 (Summer \& Autumn 2014), 260-272 
When one examines the history of submarine procurement in Canada, two themes stand out: the Canadian government has been unwilling to invest in a submarine building capability within Canadian shipyards, and it has been reluctant to purchase submarines from a foreign source. What is more is that the government will only accept a foreign acquisition if there is a reciprocal arrangement to offset the cost. The Oberonand Victoria-class programmes are cases-in-point and this paper will examine these two acquisitions with a view of focusing on the main efforts to create and maintain a Canadian submarine force that resulted in the establishment of the $1^{\text {st }}$ Canadian Submarine Squadron on the east coast in the mid-1960s. So as not to distract from that discussion, the short-term acquisition of American submarines (Grilse and Rainbow) to provide target submarine duties on the west coast will not be discussed, as it is not considered part of the main staff efforts to establish an operational submarine service according to the navy's files from the period.

Similar to the Australian experience, the story of Canadian submarine acquisition has been largely influenced by both American and British production and design. Indeed the Royal Australian Navy (RAN) and the Royal Canadian Navy (RCN) have both depended on Britain for submarines for training other fleet units, to the point that the Royal Navy's (RN) $4^{\text {th }}$ and $6^{\text {th }}$ Squadrons respectively were based in Sydney and Halifax during the 1950s. Furthermore, from the 1960s to the 1990s, both navies operated British Oberon-class diesel-electric submarines obtained from the construction programme in the United Kingdom. Where these experiences differ is that, despite having little industrial capacity for submarine construction, the Australians went on to build their own submarines to replace the Oberons, whereas Canada went back to Britain for yet another offshore purchase only after a reciprocal agreement was arranged. This is despite Canadian industry having experience building complete submarines for Britain prior to the First World War and portions of hulls for the US Navy during the Cold War. ${ }^{3}$

Some may find it surprising that the first serious attempt to establish an indigenous attack submarine capability in Canada actually started with a nuclear programme in 1959. In fact, as early as 1949, some within the RCN's Technical Services believed that nuclear fission should be investigated as a means of warship propulsion. The idea took hold within the technical community and included as an option for future shipbuilding programmes. ${ }^{4}$ Then, in 1957, the RCN's Director of Undersea Warfare, Captain Patrick Russell, drafted a pivotal study that challenged conventional thinking within the RCN. His A/S Weapons Systems Effectiveness Study, promoted the

3 Before the First World War, Canadian Vickers in Montreal built submarines for the Royal Navy in collaboration with the Electric Boat Company in the US and went on to build sections of submarine s for the US nuclear submarine programme in the 1960s. See J. David Perkins, The Canadian Submarine Service in Review (St. Catherines: Vanwell, 2000); and Julie Ferguson, Through a Canadian Periscope: The Story of the Canadian Submarine Service (Toronto: Dundurn Press, 1995), 260.

4 Michael Whitby, "Vice-Admiral Harry G. DeWolf: Pragmatic Navalist," in Michael Whitby, Richard H. Gimblett and Peter Haydon (eds.), The Admirals: Canada's Senior Naval Leadership in the Twentieth Century (Toronto: Dundurn Press, 2006), 231-232. 
aircraft/submarine combination as the most effective system against enemy submarines. ${ }^{5}$ The idea merged with the pursuit of nuclear propulsion and became the basis for a proposal for the creation of an operational RCN submarine service with nuclear-powered submarines constructed in Canada. The concept and recommendations were endorsed by the Naval Staff in October 1957 and approved by the Naval Board. ${ }^{6}$

The Chief of the Naval Staff, Vice-Admiral, Harry DeWolf, supported the acquisition and was impressed by the technology, particularly after he sailed in USS Seawolf in December 1957. ${ }^{7}$ The following year, the Nuclear Submarine Survey Team (NSST) was formed to investigate the acquisition of nuclear-powered submarines. ${ }^{8}$ The group of experts was made up of representatives from the navy, the Department of Defence Production, and Atomic Energy of Canada Limited (AECL). ${ }^{9}$ Over the course of a year-long study, they determined that the Canadian shipbuilding and nuclear power industries could handle a production programme. The platform of choice was the US Navy's coveted Skipjack-class design. ${ }^{10}$ Skipjack was the world's first modern generation II nuclear attack submarine combining the experimental hydrodynamic teardrop shaped hull with the successful S5W reactor. ${ }^{11}$

Yet before the report was tabled, support began to wane as the huge cost of a nuclear programme became apparent. In February 1959, the first interim report identified massive infrastructure requirements including the provision of shore facilities for refit and refuelling as well as large shore-based Very Low Frequency (VLF) facilities necessary to communicate with a submerged submarine. In March 1959, the Ottawa Journal reported comments by Defence Minister George Pearkes stating that the huge cost was the biggest obstacle to building nuclear submarines for the Royal Canadian Navy. ${ }^{12}$

It also was becoming clear that the head of the American nuclear programme, Rear Admiral Hyman Rickover, was adamant about safeguarding restricted US data on nuclear submarine technology and actively opposed any transfer to another country. ${ }^{13}$ There was, however, one exception. While the NSST was studying Canada's ability to take on a

5 Directorate of History and Heritage (DHH), 79/246, file 110.

6 DHH, 81/520/1000/100/2, box 25, file 3,NB, 552-2, 20 November 1957.

7 Whitby, "Vice-Admiral Harry G. DeWolf," 234.

8 DHH 79/246, folder 10,Terms of Reference, Report of the Nuclear Submarine Survey Team, June 1959.

9 The US and UK had already established similar advisory committees with representation from the navy, nuclear engineering and industry. Eric J. Grove, Vanguard to Trident: British Naval Policy Since World War II (Annapolis: Naval Institute Press, 1987), 231-232.

10 DHH, 81/520/1000-100/2, box 25, file 3, NB Minute 564-4, 2 April 1958.

11 The designation stands for the class of ship the reactor is designed for followed by the version or generation of the reactor and the company that built it. In this case, ' $\mathrm{S}$ ' is for submarine, ' 5 ' is for the $5^{\text {th }}$ generation of marine reactor development, and ' $W$ ' stands for the Westinghouse manufacturing company.

12 "Pearkes Shudders to Think of Cost of Nuclear Subs," Ottawa Journal, 31 March 1959.

13 Francis Duncan, Rickover: The Struggle for Excellence (Annapolis: Naval Institute Press, 2001), 155. 
construction programme, the United States agreed to the direct infusion of nuclear submarine reactor technology into the Royal Navy's embryonic development programme. The result was HMS Dreadnaught: a British-built version of the Skipjack with the American S5W reactor - exactly what the RCN was trying to accomplish.

Realizing that the high cost and obstacles to gaining access to American technology would preclude government approval, DeWolf dropped his support for the programme. In May 1960, he publicly stated that the RCN was a defensive force whose job it was to find and destroy submarines but not by "going underwater" to combat them. ${ }^{14}$ As a "pragmatic navalist," he instead supported the creation of a submarine service for ASW training only. ${ }^{15}$

With this, the RCN turned to a conventionally-powered option of proven US or UK design to establish a submarine service. The Chiefs of Staff, the Minister and even the Cabinet Defence Committee all supported this approach. ${ }^{16}$ A second committee studied two leading designs: the American Barbel-class - a conventional version of the Skipjack - and the British Oberon-class. Again the recommendation was to build in Canadian shipyards, and the design heavily favoured was the American one. ${ }^{17}$

At the time, target submarine duties were provided by the RN's $6^{\text {th }}$ Submarine Squadron. The RAN was faced with the same problem and was also using this as an argument for establishing its own service. ${ }^{18}$ This approach was supported by the Admiralty who wanted to withdraw their submarines from both Canada and Australia so that they could assist some of the younger Commonwealth countries while still providing target services to their own navy. The RCN asked the British to send a letter to their own government to this effect, which they did. ${ }^{19}$

But submarines are a hard sell to Canadians. In August 1960, opposition began to emerge when the recommendation to build Barbels in Canada was circulated to other government departments. The Treasury Board, in particular, was reluctant to approve any submarine programme based on moral grounds. After investigation and discussion, senior naval officials discovered that "there is an impression in this country that submarines are almost in the same classification as poison gas." 20 To satisfy the Cabinet Defence Committee, the $\mathrm{RCN}$ had to provide reasons-in-writing explaining to the general public why the government was proposing to introduce a small number of submarines into the navy. ${ }^{21}$

14 "Navy Ready, No Cutback - DeWolf," Halifax Herald, 20 May 1960.

15 Whitby, "Vice-Admiral Harry G. DeWolf," 231.

16 DHH, 73/1223, series 1, file 404, Memo from MND to CDC, 10 March 1960 (Cabinet Document D-3-60). See also Library and Archives Canada (LAC), RG 24, acc. 83-84/167, box 3782 .

17 DHH, 79/246, folder 175, The Report of the Conventional Submarine Survey Committee, June 1960.

18 Yule and Woolner, 12.

19 DHH, 79/246, folder 175, Letter from the British Minister of Defence, to the Canadian Minister of National Defence, 14 July 1960 (NPCC project file M-1).

20 DHH, 79/246, folder 175, Memo from NComp to VCNS, 2 August 1960 (NPCC project file M-1).

21 DHH, 73/1223, Series 1, File 404, Record of Cabinet Defence Committee Decision, $132^{\text {nd }}$ 
The naval staff concluded that the reason submarines had such a stigma was because in both world wars, they had become associated with being a weapon of the enemy and "synonymous with evil.", Indeed, many Canadians still remembered the Battle of the Atlantic and the use German submarine wolf packs to prey on merchant shipping. The solution was to market submarines as a defensive weapon against enemy submarines claiming that, "[i]t is in this role of the 'submarine killer' that the RCN wishes to embark on a submarine building programme." ${ }^{23}$ Since the late-1950s, Canada's naval planners have understood the strategic, operational and tactical advantages of operating submarines. The problem has always been how to explain this to generations of Canadians who were conditioned to believe that submarines are a weapon of the enemy and therefore reprehensible. It is here that confusion sets in as to whether or not the submarines were for training or operations. If submarines cannot be acquired for an offensive role, the only agreeable rationale, therefore, was to operate a small number acting as 'enemy' targets for the purpose of training surface and air forces to combat submarines.

The Chiefs of Staff felt that the RCN might want at least to acquire three Oberons for training purposes as an interim step toward eventually building submarines in Canada. ${ }^{24}$ This would allow for the relief of the RN's $6^{\text {th }}$ Submarine Squadron in Halifax. The navy laid out a plan to purchase the three Oberons as part of phase one of a two part plan. The second phase would be to build advanced-type submarines in Canada at a later date. The Cabinet Defence Committee agreed to the phase one Oberon procurement only on the condition that a reciprocal arrangement of British purchases from Canada would be arranged to offset the cost. $^{25}$ This was the exact same plan being pursued by the RAN, which was encountering similar obstacles, yet did not suffer from the same public stigma with respect to submarines. ${ }^{26}$ Like the RCN, the RAN looked at the Barbel and Oberon designs; however, the Australian Chief of Naval Staff, Vice-Admiral Henry Burrell, was convinced that the Oberons were the best conventional submarines on the market. ${ }^{27}$ While the government wanted to investigate whether or not some of the construction could be done by Australian industry, the navy warned that a decision had to be made quickly because the Canadians were showing interest in the same programme and might order first. ${ }^{28}$ In January 1963, the Australian government approved a programme of six with the possibility of acquiring another two. Like the RCN,

Meeting, 14 September 1960.

DHH, 79/246, file 175,Memo with attachment from VCNS to CNS, 23 September 1960 (NPCC project file M-1).

Ibid.

24 DHH, 73/1223, series 3, box 63, file 1310 E, Chiefs of Staff Committee, meeting 705, item IV, 16 November 1961. from the historical review in the report of the 1962 submarine committee, July 1962. Alastair Cooper, "1955-1972: The Era of Forward Defence," in David Stevens (ed.), The Royal Australian Navy (Oxford: Oxford University Press, 2001), 188.

27 Cooper, 188.

28 Yule and Woolner, 17. 
the RAN went about planning the eventual transition to more advanced-type submarines. ${ }^{29}$

The Canadian negotiations with Britain did not go so well. Although the Minister of National Defence, Douglas Harkness, publicly announced the intention to pursue an Oberon deal on 11 April 1962, the Progressive Conservative government to which Harkness belonged became preoccupied with other priorities including the nuclear weapons controversy, an economic austerity programme necessitated by a recession, and a series of close confidence votes in the House of Commons late in 1962. Given this, Prime Minister John Diefenbaker remarked during a Cabinet meeting in February 1963 that, “... the procurement of three Oberon-class submarines from the United Kingdom was not urgent...."30 The programme would have to wait.

By April, Diefenbaker's crumbling minority government fell. The resulting federal election brought in another minority government under the former Liberal opposition leader, now Prime Minister Lester Pearson, who immediately ordered a review of all existing defence programmes. By October, Cabinet decided to acquire Oberons under a reciprocal trade deal. ${ }^{31}$ For those advocating a submarine force, this decision marked the end of a long and bitter struggle, but public acceptance was less than favourable. The shipbuilding industry was quick to turn on the government for making an offshore purchase at the exclusion of work that could have been done in Canadian yards. The decision was criticised in the media and rumours spread that there were problems with the lead submarine, HMCS Ojibwa, under construction in Britain as HMS Onyx. ${ }^{32}$

Despite bad publicity, the RCN went on to operate their new submarines throughout the 1960s and 1970s, eventually developing a close relationship with the RAN because they were operating the same platform and had common training and operating procedures based on Royal Navy standards. Mutual training occurred naturally and exchange officers from each navy filled key leadership positions in the other navy's submarines and squadron staffs. ${ }^{33}$ Both Canadian and Australian submariners continued to train with the Royal Navy.

For the most part, the Canadian boats were used almost exclusively for target submarine duties in the early years of operation. However, in 1979, the navy received approval for the Submarine Operational Update Programme (SOUP), which began with Ojibwa in December 1981. The technical upgrade consisted of replacing the original TCSS-9

29 Cooper, 188.

30 LAC, RG 2, series 5-A-a, vol. 6253, Cabinet Meeting 16-63, 26 February 1963.

31 LAC, RG 2, series A-5-a, vol. 6254, Cabinet minutes, 10 October 1963. The deal consisted of various offsetting purchases of Canadian-made products and also a share in the cost of developing the CL-89 unmanned reconnaissance vehicle. "Sub Purchase to Make Jobs Says Hellyer," Victoria Times, 24 December 1963.

32 "Shipbuilders Protest "Sub" Plan," The Citizen, 8 November 1963; "British Built Subs Less than the Best?" The Ottawa Journal, 3 November 1966.

33 Michael Whitby, “'Doin' the Biz': Canadian Submarine Patrol Operations Against Soviet SSBNs, 1983-87," in Bernd Horn (ed.), Fortune Favours the Brave: Tales of Courage and Tenacity in Canadian Military History (Toronto: Dundurn Press, 2009), 322. See also the paper in these proceedings by Laurence Hickey, "The Submarine Service: Cross-Connect Open to the Allied System." 
torpedo fire control with the state-of-the-art Singer-Librascope system developed for the American Los Angeles-class nuclear attack submarine. New MicroPUFFS passive rangefinding sonar and an upgrade to the attack periscope were also included along with updates to the communication system and new batteries to increase their submerged endurance. ${ }^{34}$ The later addition of the American Mark 48 wire-guided homing torpedo combined with the Oberons' legendary quietness gave the Canadian submarine squadron a new and formidable combat capability.

Likewise, the Australians commenced the Submarine Weapons Update Programme (SWUP) in the 1980s, which gave their O-boats the same American fire control system and MicroPUFFS sonar as well as the German Krupp Atlas attack sonar. ${ }^{35}$ In addition to the Mk 48 torpedo, the Australians also included the submarine-launched Harpoon anti-ship missile system. It was this latter upgrade that allowed HMAS Ovens the distinction of being the first diesel/electric submarine to fire an encapsulated Harpoon missile. ${ }^{36}$

With the establishment of the Submarine Warfare Systems Centre, the RAN now had the expertise to develop its own software to integrate some of the many onboard systems. This software was in many ways superior to any other in existence and allowed their O-boats to fire a salvo of six missiles that would converge on the target from multiple directions at the exact same time. ${ }^{37}$ Moreover, the success of this combat system integration gave the Australians the confidence to try a total systems integration package for their replacement project. Unfortunately, it turned out to be a complete failure. ${ }^{38}$

In Canada, plans to replace the Oberons continued to be centred on a domestic building programme of proven foreign design. Eventually, these efforts evolved into the Canadian Submarine Replacement Project (CSRP) in 1980, which evaluated a number of designs including the planned British Type 2400 Upholder-class, the Dutch Walrus-class (a $2^{\text {nd }}$ generation variant of the Barbel design), and the German Type 209. ${ }^{39}$

Since the RAN also needed to replace their Oberons, a joint venture was discussed

34 The original systems are outlined in $R C N$ ' $O$ ' Class Submarine Construction Programme, Director General Ships, no date, DHH, 79/246, folder 37. The SOUP upgrades can be found in Whitby, “Doin' the Biz"” 295.

Yule and Woolner, 23.

36 Peter Jones, "1983-1991: A Period of Change and Uncertainty," in Stevens (ed.), The Royal Australian Navy, 221.

37 Yule and Woolner, 25.

38 The largest failure of the Collins-class project was that of the Rockwell Combat Data System. Eventually, all attempts to fix the numerous problems were abandoned. Total systems integration is something that experienced submarine builders and designers have attempted with equal failure including the USN. See: Maryanne Kelton, "New Depths in Australian-US Relations: The Collins-Class Submarine Project" (Working Paper, School of Political and International Studies, The Flinders University of South Australia, March 2004); and Derek Woolner, "Getting in Early: Lessons of the Collins Submarine Programme for Improved Oversight of Defence Procurement" (Research Paper \#3 2001-02, Parliament of Australia, Parliamentary Library, 18 September 2001). 
with the Canadians. The Australians were interested in building their own submarine and marketing them to both Canada and New Zealand. In 1983, the Canadian navy opened a project office under the title Canadian Submarine Acquisition Project (CASAP) and a motivating factor for the project was that the RAN had forwarded their Statement of Requirements, request for tender, and an "official invitation for Canada to observe their design evaluation process." 40 This eventually led to a Memorandum of Understanding between Australia and Canada for cooperation in identifying and acquiring an Oberon-class replacement. $^{41}$

A Canadian technical team worked alongside the RAN Project Office to determine if the programme was suitable for Canada. ${ }^{42}$ Eventually, a cabinet proposal was put together for a joint Canada-Australia venture for the production of between 4 and 12 diesel-electric submarines. ${ }^{43}$ Despite the project's initial promise, three things derailed it: first, the Assistant Deputy Minister (Material) put a hold on the project so that it would not jeopardize the Canadian Patrol Frigate (CPF) programme; second, there was too much risk being built into the programme since much of what the RAN wanted did not exist and required many changes to the original design with no existing support; ${ }^{44}$ and third, allegations of collusion were emerging from the RAN project. ${ }^{45}$ In Canada, the navy's future submarine programme also became involved in somewhat of a controversy.

In 1987, the Progressive Conservative government of Prime Minister Brian Mulroney released its White Paper on Defence and announced the intention to obtain 10-12 nuclear submarines, shocking many within the defence establishment. At this point, one might wonder, how a conventional submarine programme came to be transformed into what would become one of the most ambitious military procurement programmes in the Canadian history? One account suggests that the nuclear submarine proposal actually evolved out of an incident in 1985 when then-Minister of National Defence, Erik Nielsen, attended a CASAP briefing and asked why the navy was not looking at nuclear propulsion for the replacement project. $^{46}$ Furthermore, according to this account, Arctic sovereignty later became a justification for the government's new defence policy, of which the acquisition of nuclear submarines was an integral part.

There is, however, more to this explanation based on a series of interesting events. First, the account of what the Minister said is not complete according to the context of the time. The Minister was asking why the project team was not looking into nuclear propulsion

40 Ferguson, 302.

41 Ibid.

42 Yule and Woolner, 200.

43 Ferguson, 302.

44 Perkins, 156.

45 Julie Ferguson, 303, writes that the RAN was steering its project toward industry and later found guilty in 1985 of rigging the evaluation process. Yule and Woolner, 84, provide more to this account by adding that one of the two consortiums was given a copy of questions prior to a Q\&A session with the Australian Liberal Party Caucus. A subsequent RAN inquiry confirmed that the document had originated from the Project Office. 
because he was told that they were the only platforms that could operate under the ice and Canada needed a capability in the North because of recent events that made it a hot political issue. ${ }^{47}$ This is an important distinction to the earlier explanation in terms of the 'cart' and the 'horse.' The Minister had requested the meeting late in August 1985, after the Polar Sea controversy reached national news. CBC news reporter Wit Fraser broke the story in late July as the American icebreaker was preparing to make its voyage, stating that it was "quickly on its way to becoming an emotional, nationalistic issue." 48 Aside from being the Deputy Prime Minister and Minister of National Defence at the time, Nielsen had been representing his home riding in Canada's north for nearly 30 years. Arctic sovereignty was not merely being used as a means to justify a nuclear submarine programme; it was, in fact, the proposal's raison d'être. After the meeting, Nielsen ordered the Nuclear Submarine Option Study, which evolved separately from CASAP. ${ }^{49}$

Second, the Government of Canada, not the navy, announced it was going to pursue a programme of 10-12 nuclear submarines, with no indication given to the CASAP project team or the industry consortia. In fact the Project Manager learned of this as he sat in the gallery in the House of Commons the day the new Minister of National Defence, Perrin Beatty, introduced the White Paper, ironically titled Challenge and Commitment. ${ }^{50}$ This in itself is a red flag that the procurement was politically motivated and not driven by the department.

Third, when most people think of the 1987 nuclear submarine proposal, they think of the controversy surrounding it. The project created fractures within the department and the navy; it did not follow normal procedures for Major Crown Projects and it was the crown jewel of a new defence White Paper only to be cancelled just two short years after its surprise announcement. What is often forgotten is that there was a federal general election in between.

In 1988, Prime Minister Brian Mulroney’s Progressive Conservatives were seeking a second straight majority. According to his memoirs, Mulroney felt that Canadian Arctic sovereignty was going to be a large hurdle and one his government had been wrestling with for almost its entire first mandate. He recounts comments to President Ronald Reagan in March 1986, that "[t]he voyage of the U.S. Coast Guard's Polar Sea through the Northwest Passage the previous summer was still a major political issue for my government," another recollection refers to it as "a great embarrassment." 52

From 1985 to 1988 , Arctic sovereignty was one of the top three topics of concern

47 Interview with the CASAP Project Manager conducted for thesis research, Jason M. Delaney, "Naval Procurement: An Analysis of Governmental Decision-Making" (MA thesis, University of Waterloo, 1999).

The Polar Sea Controversy, CBC news clip, 29 July 1985, in CBC Digital Archives Website, http://archives.cbc.ca/politics/federal_politics/clips/13655/(accessed May 2010).

49 Delaney, "Naval Procurement."

50 Ferguson, 308.

51 Brian Mulroney, Memoirs: 1939-1993 (Toronto: McClelland, 2007), 430.

52 Ibid, 452. 
between Canada and the United States; free trade and acid rain were the other two. Later in April 1987, Prime Minister Mulroney told US President Ronald Reagan that if there were a direct challenge to Canadian sovereignty in the Arctic, he would be "obliged to take all kinds of action" to ensure that his government was not "blown out of the water." 53 On 5 June 1987, the White Paper was released with its three oceans policy setting Canada's defence priorities in the Atlantic, the Pacific and the Arctic. Nuclear submarines, along with Polar 8-class icebreakers (also proposed in 1985) were going to be the champions of Canada's sovereignty in the North and the government was sending a strong message to the US that they were serious. Defence Minister Perrin Beatty was quoted as saying “... policy without the acquisitions would be mere rhetoric", and "the nuclear-powered submarine project is central to the development of a three ocean navy." 54

Fourth, when the choices were narrowed down to two designs and the country of origin was ready to be announced, a Cabinet meeting was scheduled for 11 May 1988 to discuss the option; but this meeting never took place. Acting on Mulroney's behalf, Secretary of State for External Affairs Joe Clarke cancelled the meeting after reading a Treasury Board briefing note brought to his attention by the Privy Council Office on 8 May. ${ }^{55}$ The briefing note outlined serious discrepancies in the programme and why it should not go further. After the meeting was cancelled, the programme was never officially discussed again until its cancellation almost a year later in the 1989 federal budget. Funding for the Polar-8 icebreaker also was reduced in the 1989 budget, and that project was officially cancelled the following year. By this account, the cancellation of the meeting on 11 May marked the demise of the programme.

But again, there is more to this story. Perhaps another explanation is that the demise of the nuclear submarine programme occurred five months earlier, on 11 January 1988 when Secretary of State for External Affairs Clarke signed the Canada-US Agreement on Arctic Cooperation on behalf of the Government of Canada. The agreement was offered by the US because Ronald Reagan liked and respected Brian Mulroney, and had directed his staff to give the Prime Minister an out on the Arctic sovereignty affair. ${ }^{56}$ The Arctic Cooperation Agreement in 1988 represented President Reagan's concession to Prime Minister Mulroney on the issue of Arctic sovereignty and the Northwest Passage. ${ }^{57}$ The extremely brief, one page agreement includes the clause: "The Government of the United States pledges that all navigation by U.S. icebreakers within waters claimed by Canada to be internal will be undertaken with the consent of the Government of Canada." $" 58$

The emotional and nationalistic issue of the Polar Sea incident was settled and the

$53 \quad$ Ibid, 497.

54 Perrin Beatty in "White Paper Provides a Framework: Challenge and Commitment: A response to Today's Issues," Defence News, 20, 21 December 1987.

55 Ferguson, 323.

56 Mulroney, 498-500.

57 Mulroney.

58 United Nations Treaty Series vol. 1852, no. 31529, Agreement Between the Government of Canada and the Government of the United States of America on Arctic Cooperation, 11 January 1988. 
government no longer had to face it in the up-coming election. The Progressive Conservatives won their second straight majority in an election fought almost exclusively over free trade.

The replacement project closed its office in 1990 and re-emerged the following year as the Canadian Patrol Submarine Programme (CPSP). With a new Conservative Defence Minister, Marcel Massé, supporting a policy of six new diesellelectric submarines together with a second batch of CPFs, twelve Maritime Coastal Defence Vessels (MCDVs), and an Arctic underwater fixed surveillance system, the prospects for the navy looked good.

The class desk officer for submarine replacement at the time was Commander Richard Payne who had identified several contenders including all those evaluated by CASAP plus a few new ones: the Swedish Type 471 and the French conventional version of the Rubis/Amethyste. But, in 1993, the programme was deferred because of yet another federal election and the relaxing of national defence priorities due to the end of the Cold War.

The world changed and defence was now less of a priority on many national agendas. In Britain, only four of the conventionally-powered Upholder-class were built out of an originally planned programme of 18 and they were immediately laid up after the Admiralty's decision to concentrate diminishing post-Cold War resources on their nuclear programme. ${ }^{59}$ With these vessels sitting idle, the Royal Navy was eager for a Commonwealth navy to take them on. ${ }^{60}$ From an allied perspective the idea of Canada acquiring and operating these submarines was ideal because both the US and Royal Navies were, by this time, operating only nuclear fleets, and therefore needed conventional submarines to exercise against. This was a key consideration in the relationship between the US and Australia as well, especially when the USN was asked to help solve some of the problems with their replacement programme, the Collins-class, particularly with respect to the combat system and interoperability with the US fleet.

Despite the desirability of Canada operating the Upholders from an allied perspective, getting the government even interested in signing-off on the acquisition was almost impossible. From this point onward, the programme flip-flopped, was renamed the Submarine Capability Life Extension Project (SCLE, an acronym pronounced by some wags as "Sickly") and plodded along with no real attention to requirements or design specifications because the work had already been done. The available options were well known and the Upholder class deal was the best on the table. According to the project leader, there was no other comparable option; yet, the programme languished for another four years. ${ }^{61}$ In the eyes of politicians and the general public, any military necessity for having submarines appeared

59 Perkins, 155.

60 Director General Material Equipment and Project Management (DGMEPM), Commodore R.W. Greenwood to author, 19 April 2010. Then-Commander Greenwood was the second Project Manager of the CPSP/SCLE project after Rick Payne. See passim the paper in these proceedings by Richard Greenwood, “An Engineer's Outline of Canadian Naval History, 1970-2014."

61 DGMEPM to author, 19 April 2010. 
to have vanished with the end of the Cold War. During this pseudo-moratorium, the British patiently waited for a final answer as to whether or not Canada would accept their offer, despite other navies expressing interest.

In April 1998, the decision finally was made with the inclusion of British offsets to the cost in much the same way as the Oberon deal 35 years earlier. The last of the Oberons were paid off at the beginning of the new millennium, just as the new submarines were being accepted. With this, the Canadian submarine force transitioned to a new platform, but it has been a long and difficult road to get them to sea.

The RAN, on the other hand, felt the Upholder-class was unsuitable for their requirements, despite the high level of technology in the design. The Australians needed a long-range submarine capable of up to 10,000 nautical miles range and greater 'at sea' patrol days. $^{62}$ Instead, they preferred the Swedish Type 471 design for its promise of transfers of technology and construction techniques, despite the fact that the original design would have to be extensively modified. In 1987, two days before the Canadian government announced its Challenge and Commitment White Paper, the Australian Commonwealth signed a contract for six new conventionally-powered submarines based on the Swedish (Type 471) Vastergotland-class built by Kockums. The winner of the competition to build the submarines in Australia was the Australian Submarine Corporation formed to bid on the multi-billion dollar project.

Submarine construction facilities were built from scratch in Port Adelaide, South Australia on undeveloped land where the construction took place between 1990 and 2003. Since the first steel was cut, the project experienced a multitude of problems that carried through to sea trials, acceptance and after. Yule and Woolner refer to the programme as, "Australia's largest, most expensive and most controversial military purchase." ${ }^{63}$ In July 1996, as the Canadian navy waited for a decision on the Upholder deal, HMAS Collins was commissioned into the fleet - albeit eighteen months behind schedule. Notwithstanding the negative publicity and first-of-class problems, what the Australians have been able to accomplish with the programme is remarkable in many areas, and for the most part far beyond what most nations would be willing to do. ${ }^{64}$ Yule and Woolner quote the former head of US submarine development and construction as saying

It was no small feat to make a small Swedish submarine with short range into a large, long-range submarine. It is really a radical new design. And then to take the design 12, 000 miles away and build it - there is really nothing in the history of submarine construction that has been done like that.... In the case of Australia, they built a whole new construction facility - a new yard, with a new workforce. It was a huge undertaking, a monumental feat and a credit to Australia, to Kockums and to ASC. ${ }^{65}$

62 Yule and Woolner, 65-66.

63 Yule and Woolner, Introduction.

64 The author appreciates that the majority of the primary source documentation on the project remains classified and thus precludes a full and balanced analysis until such a time as they are made available. 
They produced a high technology attack submarine capability built in Australia by Australians at a time when there were very few national resources to do so. With one programme, the Australians built themselves a highly successful shipbuilding and technology sector that still exists today, and is actively involved in both in-service support to the Collinsclass and the new Air Warfare Destroyer programme.

Subsequently, Australian defence policy committed to a follow-on submarine programme to be built in South Australia by the nationalized ASC and they have the capacity to do it. Indeed, their prospects for building their own submarines suited to their unique security requirements in the South Pacific are extremely bright. Canada, on the other hand, is a different story.

With the Canadian navy's transition to the Victoria-class, where does the Canadian submarine service go from here? In the past, Canadians have never really understood any justification for submarines because of their reputation as a weapon of the aggressor and a lack of validation even during the Cold War. The closest the navy came to pursuing a large domestic procurement programme, the Nuclear Submarine Option Study, turned out to be about sovereignty and not submarines. After the end of the Cold War, with no clear and imminent threat from enemy submarines, and the long list of other priorities on the national agenda, the navy has been hard-pressed to convince Canadians that submarines are justified in the RCN's order of battle. For the Australians, with a Labour government in the middle of a severe recession in the early-1980s following a policy of Australian self-reliance in defence capability, the approval of a high-technology, manpower-intensive national construction project went almost without opposition. In fact, state governments campaigned over which one would be awarded the construction site and put their local communities to work. The investment in their own workforce and industry resulted in a successful submarine construction and industrial capacity such that the RAN could move forward independently; Canada cannot.

In Canada, submarines remain a hard sell to politicians and the general public. The closest the nation ever came to a domestic building programme was in 1959-62 before the decision to acquire the Oberon class in 1963. Later in 1987, the proposal to build nuclear submarines in Canada emerged out of the political need to address the Arctic sovereignty issue. Interestingly, programme supporters attempted to transform the reputation of the submarine into one of being the defender of Canada's sovereignty. Yet, when the political necessity was removed, the programme had no staying power.

From this overview, two conclusions can be drawn that pose tremendous obstacles to any future programme. First, the Canadian government has never been willing to invest in an indigenous submarine building industry and are prepared to acquire off-shore and off-theshelf provided there is a reciprocal arrangement to offset the cost. Second, the procurement source for submarines has traditionally been both the United States and the United Kingdom, neither of which any longer produce conventionally-powered submarines. So the question is: where does the Canadian submarine service go from here? In contrast to the Australian experience, submarines remain one class of vessel that is impossible to build in Canada. 